\title{
On the Way to Improve the Employment Quality of College Students in the New Era \\ Wang Guoqing*
}

Heilongiiang Bayi Agricultural University, Daqing City, Heilongjiang Province, China

DOI: $10.36347 /$ sjavs.2020.v07i05.003

| Received: 24.04.2020 | Accepted: 04.05.2020 | Published: 16.05.2020

*Corresponding author: Wang Guoqing

\section{Abstract}

The employment of college students is the focus of the work of college students, and the difficulty of employment of college students has become an increasingly prominent problem. This paper deeply analyzes the challenges faced by college students and colleges, the causes of employment difficulties, and the countermeasures and suggestions to improve the quality of employment of college students, gradually improve the system construction, improve the employment service, improve the employment ability, and strive to improve the employment quality of College Students.

Keywords: Employment work, College student, Quality of employment.

Copyright @ 2020: This is an open-access article distributed under the terms of the Creative Commons Attribution license which permits unrestricted use, distribution, and reproduction in any medium for non-commercial use (NonCommercial, or CC-BY-NC) provided the original author and source are credited.

\section{INTRODUCTION}

In the new situation, for colleges and universities, improving the quality of employment is an important requirement to adapt to the innovative development of the employment work in Colleges and Universities under the new situation, and also an important measure to promote the strategy of strengthening the country with talents [1]. However, college students show the phenomenon of insufficient employment ability, poor stability and fierce competition. Therefore, to improve the quality of College Students' employment is an important work in Colleges and universities.

\section{The challenge of College Students' Employment}

Employment is an important part of talent training in Colleges and universities, and also an important indicator to measure the quality of talent training in Colleges and universities. At present, some students have some ideological problems, such as lack of employment awareness, low subjective enthusiasm, and inadequate preparation for the new situation of employment [2]. The lack of systematic thinking on their own professional knowledge, interests and career development path has a serious impact on the quality of employment.

First of all, the quality of employment guidance needs to be improved. The employment guidance in Colleges and universities is a professional work, which has higher requirements on the management, professional quality, resource allocation and other aspects of colleges and universities. In the current employment guidance work, there are still some objective factors that affect the quality of college employment guidance work. In the current employment guidance work, there are still some objective factors that affect the quality of college employment guidance work. On the one hand, in the process of organization and employment guidance, institutions, staffing and funding are still inadequate. It is difficult to give full play to the function of employment guidance and solve the problem of students' Employment. On the other hand, the degree of social support for college students' employment affects the employment expectation of some students and the employment concept of some enterprises. Therefore, it has an important impact on the employment quality of college students.

Secondly, the comprehensive strength of some students' employment is insufficient. The employment ability of contemporary college students needs to be further improved. For example, there is a lack of target enterprises, a lack of understanding of the demand for post ability and so on, which leads to the failure of job hunting. Due to the lack of objective analysis, imitation of other people's decision-making and excessive dependence on market public opinion, some college students are blindly crowded into hot jobs and hot cities. It not only has a negative impact on the employment concept of college students, but also intensifies the situation of the employment difficulty of 
college students [3]. In the process of seeking jobs, some students are lack of pertinence, purpose, employment goal and career planning, which leads to the employment credit crisis and great waste of social resources.

\section{The causes of College Students' employment difficulties}

At the government level, First of all, the effectiveness of some employment policies needs to be improved. Mainly reflected in the lack of clear incentive measures, policy conditions and future sustainable development system for guiding policies. Secondly, System of Practice practice is not perfect[4]. The role of internship government in strengthening corporate social responsibility, leading school enterprise cooperation, and building practice platform is relatively weak. It indirectly leads to the lack of practical awareness and experience of some students.

On the level of school employment education mechanism, first of all, the disjunction between some personnel training systems and employment work. Therefore talent training system and employment work need to be coordinated and unified. Secondly, many colleges and universities have less curriculum arrangement for career planning and less experienced teachers. Therefore, the importance of vocational planning education needs to be further improved. In some colleges and universities, the form of vocational planning education is single, the class hours are few, the attention is insufficient, and the effect is not high, which makes it difficult for students to improve their employment ability and quality. The last, It is difficult for the traditional employment guidance education to effectively mobilize the enthusiasm of students. The links of teaching and practice are not innovative and attractive enough in the employment guidance education [5].

At the personal level of students, first of all, College students have short preparation time and insufficient preparation. During the freshman year, there was little consideration of career planning and employment. It was not until the senior year that we began to understand employment, which made it difficult to improve the overall quality and ultimately led to inadequate preparation. Secondly, Passive access to employment information, single channel. Most of the channels for students to apply for jobs are the job fairs organized by the school and the recruitment information released. The passivity of information acquisition leads to the incomplete information of some students, which is easily influenced by public opinion, lead to aggravating the structural contradiction of College Students' Employment. The last, lack of practical experience. University is the key period for students to improve themselves [6]. The lack of practical experience makes it difficult for students to understand themselves. In the process of employment, there is a lack of pertinence, purposefulness and expectation deviation.

\section{Countermeasures and suggestions for improving the quality of employment}

To improve the employment quality of colleges and universities, we need to make concerted efforts in many aspects. Strive to form a good situation in which the government creates a good employment environment and conditions, colleges and universities improve the quality of personnel training and employment work, and college students improve their enthusiasm for employment.

The government strengthens management and ensures overall decision-making. First of all, we should strengthen the guiding role of policies and ensure that policies focus on effectiveness. In order to change the concept of employment, the whole society should actively guide the formation of correct concept of employment and values, and create a good atmosphere to serve the community. In addition, guarantee employment policy to fully protect the rights and interests of College Students. Secondly, strengthen the service function of government employment work and build practice platform mechanism to improve the quality of employment. With reference to the experience of advanced countries, we will strengthen the cooperation between schools and enterprises led by the government, and strengthen the construction of internship platforms. Follow up and supervise the needs, conditions and results of practice, ensure the effect of practice through continuous adjustment and improvement, and practically improve the practical ability and employment ability of students.

Colleges and universities need scientific planning to guarantee the quality of employment service. First of all, colleges and universities should insist on the cooperation of all employees to strengthen the construction of employment team. In classroom teaching, teachers should respect the individual differences of college students and establish a scientific and systematic evaluation system. In daily management, teachers should help students to recognize their abilities and find suitable development direction. And guide the students who have the ability and need to participate in the research, in-depth understanding of professional applications. At the same time, it is necessary to establish a sound assessment and evaluation system to ensure the penetration effect of the whole process of employment.

Improve students' employment initiative and motivation. College graduates' self-awareness plays a positive role in promoting job-hunting behavior[7]. The improvement of self-efficacy will help to improve employment ability, increase employment enthusiasm and success rate. First of all, we should weigh ourselves 
reasonably and objectively. Know yourself and yourself in all aspects by means of assessment, asking teachers and students around you, etc. Secondly, we should aim at our own interests, hobbies and abilities, make clear the direction of career choice, and set up our career goals. Finally, we need to set goals, establish career planning files and career planning files. Meanwhile, Combine personal employment with social demand, combine personal employment with social demand, strengthen practical activities, and cultivate social responsibility and dedication to improve the quality of employment. Improve the employment ability of college students through practical activities.

\section{REFERENCES}

1. Zhao Peng. Research on the strategy of improving the employment quality of College Students under the background of "mass entrepreneurship and innovation" [J]. Quality education in the West. 2018(20):163.

2. Deng Jinsong. The present situation and Countermeasures of the employment quality of college students [J]. Industry and Technology Forum. 2018(04): 265.

3. Zhu Lingwei. A study on the way to improve the employment quality of College Students[J]. Education modernization. 2019(58):28-29.

4. Zhao Ming. A study on the countermeasures to improve the employment quality of Modern College Students [J]. Jiangsu Higher Education. 2019(10):67-72.

5. Li Jinlin, Ying Weiqing. On the construction of scientific evaluation system of employment quality in Colleges and Universities [J]. Modern Education Science, 2015(03):60-62.

6. $\mathrm{Ke} \mathrm{Yu}$. Investigation and trend analysis on the employment quality of university graduates $[\mathrm{J}]$. Research on Heilong higher education. 2010(07):106-108.

7. Chen Yuanpo. Research on the construction and application of the evaluation index system of College Students' Employment Quality [J]. Journal of Anhui Institute of water resources and Hydropower Technology. 2018, 18(07):93-96. 